\title{
Learning Style Dimensions and Professional Characteristics of Academic Librarians
}

\section{Amanda Rinehart, Jennifer Sharkey, and Chad Kahl}

Do librarians with different characteristics, such as type of work responsibilities or age, have different learning styles? The authors analyzed results from over 1,500 responses to a version of the Index of Learning Styles (ILS) questionnaire based on the Felder-Silverman Learning Styles model. This model consists of eight dimensions paired on four scales: Active/Reflective; Sensing/Intuitive; Visual/Verbal; and Sequential/ Global. In addition to their scores on the ILS questionnaire, respondents were also asked about demographic and professional characteristics. Statistically significant differences in learning style scores were found to exist between librarians with different types of position responsibilities. In particular, for three out of four scales, catalogers have statistically different learning styles than other librarian groups. Recognition of different learning styles and thoughtful integration of appropriate teaching styles may improve workplace interpersonal communication, enhance professional development and staff training, and strengthen teaching.

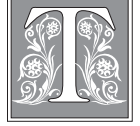

he study and assessment of learning styles have been significant components of educational theory and practice for decades. Contemporary research of how the cognitive differences of students affect their ability to learn and retain new knowledge gained prominence in the late 1970s and became a major focus within many academic disciplines in the 1980s as several major theories and schools of thought were established. ${ }^{1}$ Although theories about learning styles are not without controversy, some key studies have shown learning styles do have a place within learning environments when tested in a valid way and used in conjunction with other established pedagogical theories and practices. ${ }^{2}$

In light of continued interest and study of learning styles, a group of academic librarians developed a research project to explore the learning styles of academic librarians. The key question of the project was: Do librarians of different professional groups, such as type of work responsibilities, have different learning styles? The instrument used for this research was the Index of Learning Styles (ILS) questionnaire created by

Amanda Rinehart is Data Management Services Librarian at Ohio State University; e-mail: Rinehart.64@ osu.edu. Jennifer Sharkey is Head of Information Use \& Fluency in Milner Library at Illinois State University; e-mail: jsharke@ilstu.edu. Chad Kahl is Interim Associate Dean in Milner Library at Illinois State University; e-mail: cmkahl@ilstu.edu. (C) 2015 Amanda Rinehart, Jennifer Sharkey, and Chad Kahl, Attribution-NonCommercial (http://creativecommons.org/licenses/by-nc/3.0/) CC BY-NC 
Felder and Soloman and based on the Felder-Silverman learning styles model. For consistency, throughout this paper the authors use Felder-Silverman to refer to the model; the questionnaire is referred to as the ILS.

Analysis of the data shows some statistically significant relationships do exist and these indicate that further research and data analysis are warranted to determine how professional responsibilities are influenced by learning styles. The present project does not seek to settle controversies about the validity or utility of learning styles theories but rather seeks patterns that could be used to further research in this area. This initial study is a first step in determining if learning styles of librarians influence their professional paths and activities.

\section{Overview of Learning Styles}

The principal investigators have identified a large gap in the literature regarding assessment of librarians' learning styles. Also, little to nothing has been written connecting the learning styles of librarians to the learning styles of students, their impact on library-led teaching and learning initiatives, and implications for organizational culture and professional development. The present study represents an initial step toward potential research in these areas.

A large amount of research and resulting literature regarding learning styles and preferences has been generated throughout the years. Learning styles are described as "typical patterns individuals use to process information or approach learning situations." 3 In Learning Strategies and Learning Styles, Schmeck makes a distinction between a strategy and style in that learning strategies of the individual are a blend of cognitive skills allowing individuals to adapt to the situation and styles are inherent to the individual based on genetics and previous experiences. ${ }^{4}$ Learning styles can be differentiated into three distinct aspects: cognitive (information processes), affective (motivation), and physiological (biological and environmental). ${ }^{5}$ In a historical summarization of learning styles, Raynor and Riding date the development of learning styles theory back to the 1940s. ${ }^{6}$ As research and learning style models grew, many models could be categorized into three different approaches: cognitive-centered, personality-centered, and activity-centered. ${ }^{7}$ Through the late $1970 \mathrm{~s}$, the majority of the research on learning styles was focused on cognitive phenomena. ${ }^{8}$ More recently, learning styles have been categorized physiologically, as the primary senses: auditory, visual, and kinesthetic/tactile. ${ }^{9}$

A survey of the most cited authors related to learning styles showed that Kolb, Dunn and Dunn, Honey and Mumford, Gregorc, Schmeck, and Vermunt were among the top thirty most cited authors. ${ }^{10}$ In a recent survey of learning styles and the literature, Coffield et al. divided the theories into five distinct learning styles families. They are:

- Learning styles and preferences are largely constitutionally based

- Learning styles reflect deep-seated features of the cognitive structure, including "patterns of ability"

- Learning styles are one component of a relatively stable personality type

- Learning styles are flexibly stable learning preferences

- Expands the scope beyond learning styles to learning approaches, strategies, orientations and conceptions of learning ${ }^{11}$

This is distinctly different from previous categories when the field of research for learning styles was still developing and examination of the literature was fairly new. A significant amount has been written about student learning styles in educational literature and how to tailor teaching and learning to meet these preferences. Library Science literature is no exception and has been examining the incorporation of learning styles into library-related teaching for many years. ${ }^{12}$ 
There has been a limited amount of research examining learning styles of librarians. In one study, the Kolb's Learning Style Inventory was used to examine learning styles of 140 librarians. ${ }^{13}$ In a later study, the Squires Thinking Styles Test was used in a university library "to determine the possibility of predicting how a new employee would respond to various kinds of training, and how productive their activity would be within the workplace."14 In an article focusing on librarians' perceptions of PowerPoint, the VARK (visual, aural, read/write, and kinesthetic sensory modalities) inventory was given to 181 attendees of two library conferences. ${ }^{15}$

The learning styles instrument used in this research is the Index of Learning Styles (ILS) based on the Felder-Silverman Learning Styles model introduced by Richard Felder and Linda Silverman in 1988 to determine how engineering students learn and to recommend a teaching styles model to complement those learning styles. The model consists of eight dimensions paired on four scales: Active/Reflective; Sensing/Intuitive; Visual/Verbal; and Sequential/Global. As stated by Felder and Silverman, these dimensions "are neither original nor comprehensive"16 and are drawn from previous theories such as Jung and Kolb. The Felder-Silverman model defines these dimensions:

- Active learners have a preference for talking through or applying what they are learning as well as working within a group setting. Reflective learners favor contemplation of new information and working individually.

- Sensing learners like structure, details, and facts as well as seeing a clear connection to the real world. Intuitive learners like exploration of new knowledge particularly if it is abstract or an entirely new concept.

- Visual learners retain knowledge when presented in a visual manner such as charts, graphs, or video. Verbal learners retain knowledge when received in written or spoken format.

- Sequential learners advance their learning in steps or a linear manner. Global learners advance their learning more randomly and when they are able to see the big picture. ${ }^{17}$

\section{Learning Styles and Index of Learning Styles Validity}

While not the focus of this study, it is important to acknowledge the ongoing debate surrounding the validity of learning styles research models and the connection to student learning. In addition to conflicting schools of thought concerning learning styles, debate exists whether learning styles theories have undergone scientific scrutiny. ${ }^{18}$ Many studies, while not actively investigating the validity of learning styles, have questioned whether they should be applied in an educational setting. In a literature survey, Pashler et al. were unable to find scientifically valid studies proving that it is appropriate to apply learning styles to education. ${ }^{19}$ Some studies found that students who are taught with methods conducive to their learning style have shown improved performance while others have shown no measurable impact. ${ }^{20}$ As research into cognitive processes expands, there is increasing examination of methods and research results. The term "neuromythologies" was first coined in 2002 to describe "a misunderstanding, a misreading, and in some cases a deliberate warping of the scientifically established facts to make a relevant case for education or for other purposes." ${ }^{21}$ The neuroscience community has classified some common "brain-based" educational models as neuromyths: these include " $10 \%$ brain usage, left- and right-brained thinking," Neil Fleming's VARK learning style model and the theory of multiple intelligences developed by Howard Gardner. ${ }^{22}$ While this ongoing debate is interesting, the ILS that the authors chose has not been cited as a neuromyth.

As with other models, the ILS has been tested for validity and reliability since its introduction in the early 1990s. Felder and Spurlin examined the data from fifteen research articles that reported results of the ILS. ${ }^{23}$ With these data, they examined test- 
retest reliability, internal consistency reliability, interscale orthogonality, and construct validity. Their analysis found that, when used as intended, the ILS validity holds. In another study, the ILS was administered to engineering students and faculty between 2000 and 2002. The test-retest reliability was determined to be strong to moderate in each of the dimensions and the internal reliability was also found to be acceptable. Additionally, representing support of construct validity, significant differences were found between the results for faculty versus students. ${ }^{24} \mathrm{~A}$ study of internal medicine residents, who completed the ILS twice and another learning style instrument once, found the test-retest reliability was good for both the Active/Reflective and Sensing/ Intuitive scales although weaker in the Visual/Verbal and Sequential/Global scales .$^{25}$ In another study, first- and third-year medical students reported that the ILS was easier to understand than the other two learning styles instruments administered. The students felt that the ILS accurately represented their learning styles. While looking at several factors to determine validity of the ILS, there was evidence of the construct validity of the ILS in both the active-reflective and sensing-intuitive learning scales. ${ }^{26}$ A longitudinal study of medical school students testing the instrument's internal consistency and temporal stability validated both components. Data gathered from second-year and fourth-year students showed temporal stability in all of the dimensions except global/sequential. Additionally, an acceptable level of internal consistency was found and provided "evidence supporting the appropriateness of the ILS for assessing learning style preferences in undergraduate medical students." 27

\section{Methodology}

Several learning styles instruments were evaluated based on general validity, ease of access for subjects, length of time to complete and/or number of questions, question difficulty, dissemination cost, scope, and ease of data retrieval access and manipulation. A list of five potential instruments was selected for further consideration: Index of Learning Styles (Felder and Soloman), Inventory of Learning Styles (Vermunt), Learning Styles Inventory (Kolb), Learning Style Questionnaire (Honey and Mumford), and Memletics ${ }^{\circledR}$ Learning Styles Inventory.

The ILS fulfilled the necessary criteria for the research purposes and surpassed other instruments in a few significant ways. First, the full instrument could be administered on a local server. Second, permission was received from North Carolina State University to adapt the ILS to capture professional data from the respondents, while also providing feedback to participants on their preferences of the four dimensions of the learning style. PHP coding was also added to enable respondents to receive a report of where they placed on each of the paired scales. This may have served as an incentive for some participants. Third, use of this instrument was provided at no cost.

The ILS, an online self-scoring questionnaire, is used to identify learning preferences within the four-paired dimension scales of the Felder-Silverman learning styles model. Developed by Richard Felder and Barbara Soloman, the ILS is a 44-question multiple-choice survey, and each of the paired learning dimensions have eleven questions designated to them. Every question provides two answer options; these answers represent both aspects of the paired dimension. ${ }^{28}$ The answers are calculated and placed on a 22-point scale for each of the four scales. The ranking on the scale indicates an individual's preference and the level of preference. A ranking of 1 or 3 is an indication that a respondent is fairly well balanced between the two dimensions of that scale. A 5 or 7 ranking on either end of the scale shows that a respondent has a moderate preference for the indicated dimension of the scale. On either end of the scale, if a ranking of 9 or 11 is indicated, then a respondent has a very strong preference for the specific dimension of the scale. 


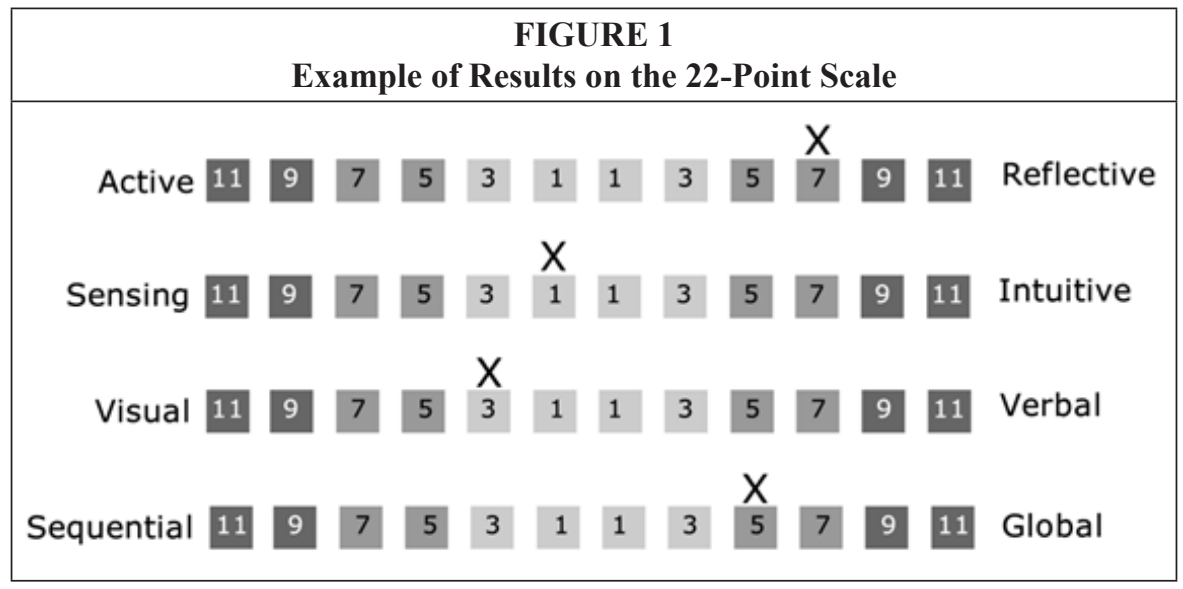

\section{Data Collection}

The online survey consisted of a set of seven questions (see appendix A), as well as the ILS questionnaire. Calls for participation and subsequent reminders to 23 listservs (see appendix B) - with a primary focus on academic librarianship-were sent. The survey was made available from April 15 to May 13, 2011. Due to a mistake in PHP coding, the survey initially was missing a legitimate answer to the birth-year question. That was corrected quickly after the survey was released. Therefore, these respondents were treated as missing data for this field. Based on feedback that the original group of listservs was too focused on public services, the survey was made available again from April 15 to May 13, 2013, and targeted toward fourteen listservs used predominantly by technical services librarians. A total of 1,576 responses was received during the two rounds: 879 in 2011 and 697 in 2013. A drawback of ILS, mentioned by several respondents, is that several questions are better suited for students in a classroom environment. It should be noted that this might have impacted how respondents of this questionnaire scored on each dimension scale.

\section{Statistical Tests}

The author's main hypothesis was that learning styles would reflect in part the type and place of work and the skills and training the librarians possessed. The null hypothesis was that there is no relationship between the learning styles for all librarians, regardless of the type and place of work or the skills and training that they possess. The following should be kept in mind when interpreting the results:

1. The four paired learning style dimensions are treated as ordinal data. This is based on arguments put forth by Carifio and Perla, that scales, as opposed to responses, can be treated as ordinal data and thus subjected to parametric statistical tests. ${ }^{29}$ Since the paired learning dimensions are measured on a 22-point scale that is calculated from 44 multiple choice questions, this theory applies.

2. For statistical analysis, the main hypothesis was separated into two subhypotheses: first, that learning styles were reliant on other observed variables (such as job position responsibilities or years in an academic library); and second, that other observed variables (such as job position responsibilities or years in an academic library) were reliant on an intrinsic learning style. Please note that, because of the nature of this observational study, there is no means of knowing which of the subhypotheses is more likely (that is to say, which came first - the learning style or the other observed variables, such as job category). Since there 
is no conclusive evidence as to whether a learning style is static and inherent or if it changes over exposure to a particular environment, both subhypotheses were considered. It is possible that a learning style may reflect both inherent qualities and environment, resulting in both subhypotheses being partially valid.

3. For the first subhypothesis (that learning styles were reliant on other observed variables, such as position responsibilities or years in an academic library), each of the four paired learning dimensions was treated as a dependent variable, with the other observed variables as the independent variables. The appropriate statistical test is an ANOVA with a Tukey-Kramer post-hoc mean separation. The Tukey-Kramer method helps to account for the differences in the sample sizes, such as that seen in the job category distribution (see table 2). ${ }^{30}$ It is more conservative than other conventional statistical tests when the sample sizes are unbalanced and thus less likely to exhibit false positives. So it is less likely to show a difference between the means, when in actuality no difference exists. However, a large difference in sample sizes does leave the analysis vulnerable to possible false negatives. That is, the analysis is less likely to indicate differences between means for the smaller sample sizes (such as the small number of scholarly communications, archives, interlibrary loan, and other librarians) even if there may be significant differences between these populations. This is because a small sample size is less likely to accurately represent its entire population. An extreme example of this is the single preservationist that responded to the survey. That individual is unlikely to represent the entire population of preservationists, and was therefore allocated into the "other" category for the analysis presented in table 2 . The only resolution to this vulnerability is to collect more data on the underrepresented populations until the sample sizes for all observed variables are large, and preferably equal, in size.

4. For the second subhypothesis (that other observed variables, such as job category or years in an academic library, was reliant on an intrinsic learning style), each of the paired learning style dimensions was treated as the independent variable, with the other observed variables as the dependent variables. The appropriate statistical test is a Chi-square or a Fisher's Exact test. However, neither could be performed due to the requirement that the values be greater than zero when the observations are separated by both the independent and the dependent variable. Therefore, in place of a statistical test, this subhypothesis is discussed with regard to observed frequencies (see figures 7-10).

Additionally, all data were analyzed with multivariate statistics to determine any patterns and/or driving forces behind any patterns. Specifically, nonmetric multidimensional scaling and principal component analysis were performed with PRIMER-E. ${ }^{31}$ No specific patterns were observed, likely due to the low (four) dimensionality of the data set. As such, no data are presented from this analysis.

\section{Study Limitations}

One limitation to this study is the nonrandom nature of the respondents. Only librarians who follow listservs received the opportunity to respond, meaning that the results may be biased toward librarians who subscribe to listservs and with an additional willingness to participate in research. It may also be postulated that those librarians who follow listservs (a learning activity) would be the most likely to be open to new learning experiences and, thus, more likely to engage in professional development activities. Therefore, the results of this study may be more applicable to the subpopulation of librarians who are more likely to engage in learning activities. The motivations, or lack thereof, for not subscribing to listservs (or other learning activities) or 
for participation in research were not within the scope of this study. However, future learning style research should focus on this population, as particular learning styles may be associated with motivational status.

Additionally, disseminating the survey via listservs allowed the authors to rapidly receive a large number of responses, something that would not have been possible with an alternative distribution method (e-mail, snail mail, or other web presence). If more than one dissemination method were used, then the possibility of multiple responses from a given individual would have increased, as well as logistical challenges. The advantage of a large number of respondents was judged to outweigh the negative impact of the volunteer bias.

\section{Results}

The survey and ILS questionnaire were completed by 1,587 respondents. The only nonprofessional question was year of birth; the rest of the survey variables focused on educational level (such as Masters in LIS) and professional characteristics: position responsibilities, supervisory responsibilities, administrative responsibilities, and type of institution.

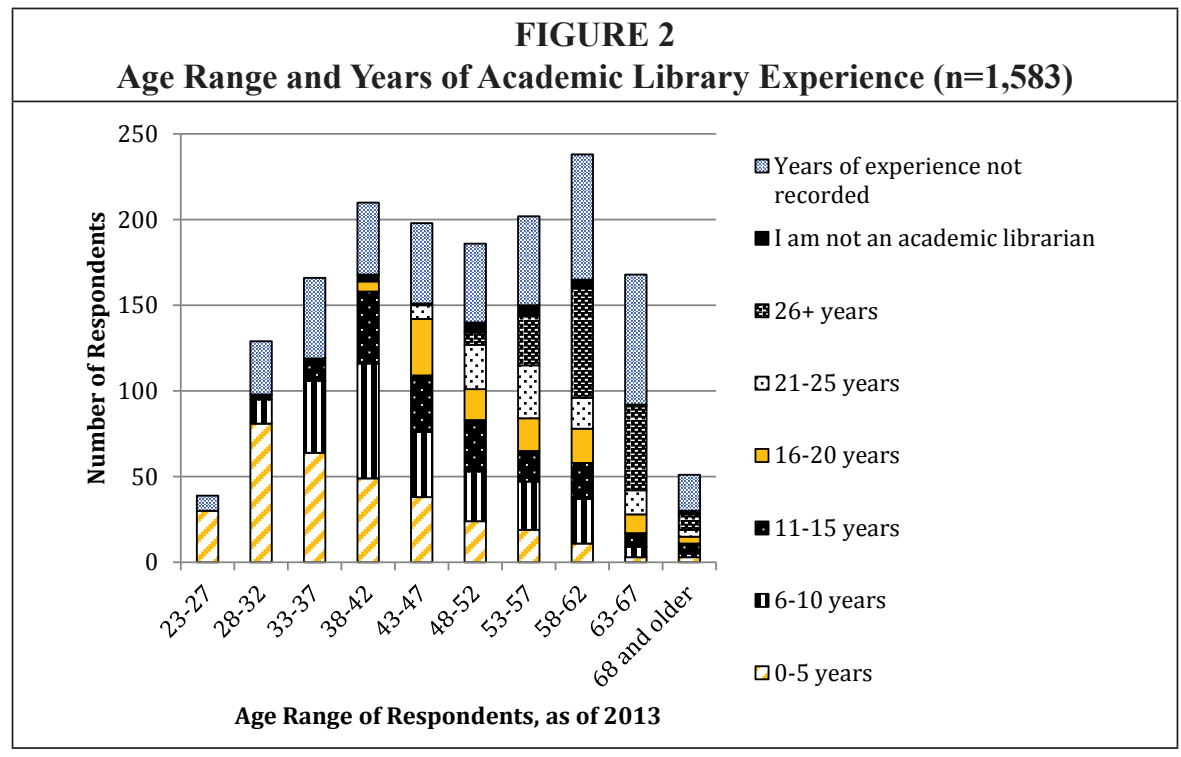

As expected in a profession that requires at least one advanced degree, most respondents ( $76 \%$ ) are between the ages of 33 and 62 (born between 1951 and 1980) (see figure 2$)$. There are slightly more librarians above the age of $62(\sim 14 \%)$ than below the age of $33(\sim 11 \%)$ (as shown in figure 2$)$. Also as expected, there is a moderately strong correlation between age and time spent in academic libraries (Pearson's $r=0.67$ ).

The three largest position responsibilities are administrative, reference, and instruction (see figure 3). Although the remaining half of the respondents are spread among the 13 remaining position responsibility categories, only one category (preservation) had fewer than 10 respondents (see figure 3). Slightly more than half of the respondents have supervisory responsibilities (55\%) and 95\% possess Masters in LIS degrees (data not shown).

The types of administrative responsibilities are relatively evenly distributed among categories (see figure 4). Similarly, the types of institutions are relatively evenly distributed (see figure 5). 

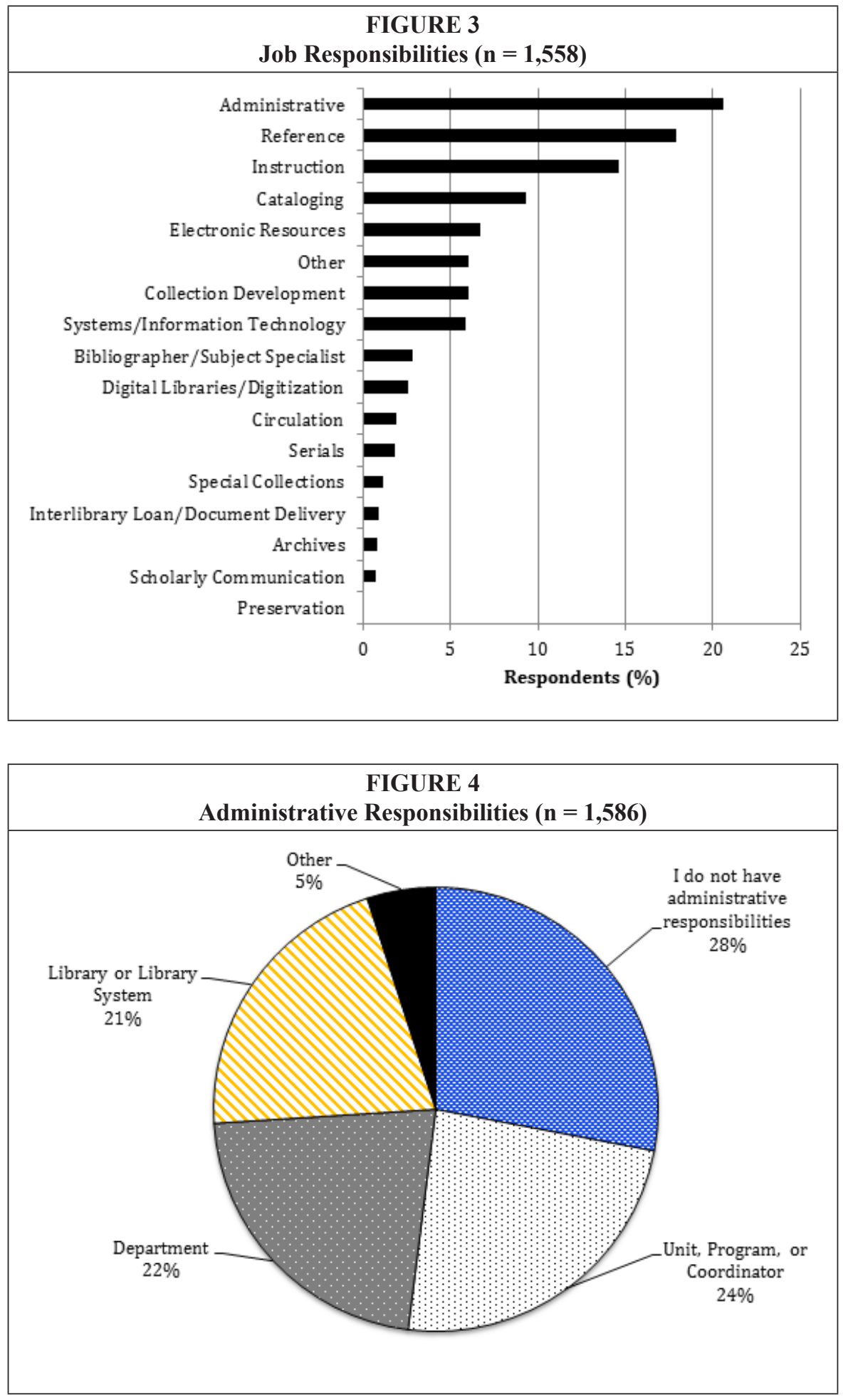


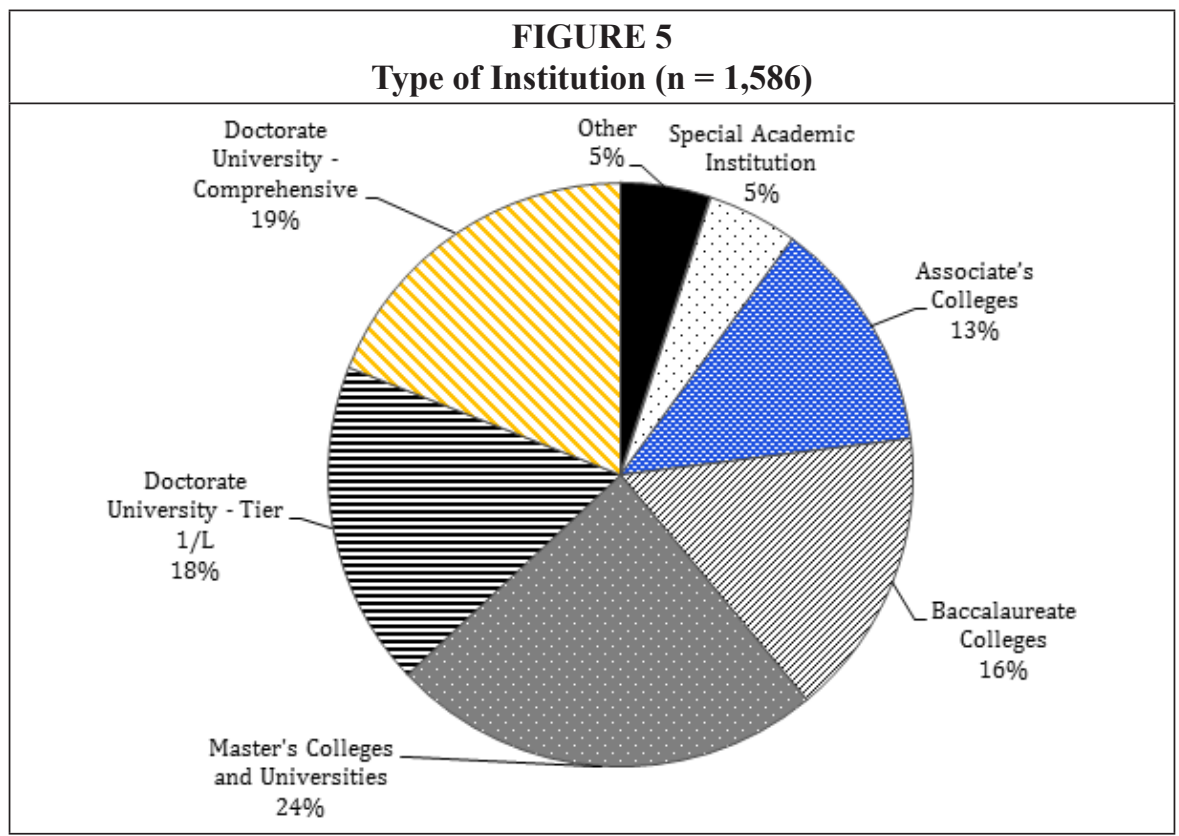

\section{Learning Style Results}

To determine if the results from both survey times (April-May 2011 and April-May 2013) were different from each other, the results were statistically compared. ${ }^{32}$ The overwhelming majority of paired learning dimension measurements are not statistically significantly different from each other ( $p>0.05$, data not shown). Therefore, the results of both survey times are combined for all statistical tests and visualizations.

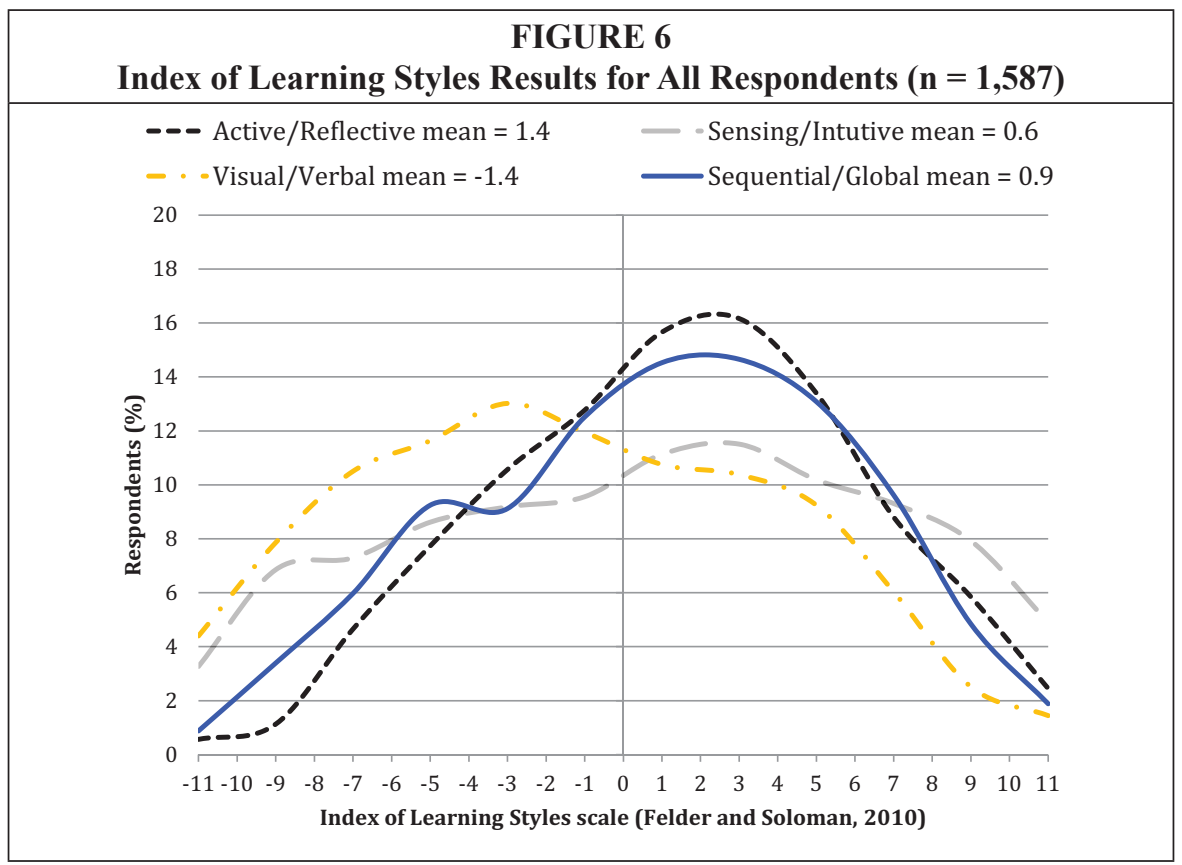


The means for all respondents are near zero; this is expected given the values range from zero to eleven on either side of the learning dimension scale. For instance, the mean for the Visual/Verbal scale shows an average negative number, but that simply means that the value is on the Visual side of the scale (see figure 6). The means for all respondents are "fairly balanced," as defined by Felder and Soloman, across all four learning dimension scales, with a slight lean toward reflective, intuitive, visual, and global learning (see figure 6).

\begin{tabular}{|l|c|c|c|c|}
\hline \multicolumn{5}{|c|}{ TABLE 1 } \\
\multicolumn{4}{|c|}{$\begin{array}{c}\text { P-values Indicating Significant Differences in the Four Paired Learning } \\
\text { Dimension Scales for All Demographic Survey Questions }\end{array}$} \\
\hline & $\begin{array}{c}\text { Active/ } \\
\text { Reflective }\end{array}$ & $\begin{array}{c}\text { Sensing/ } \\
\text { Intuitive }\end{array}$ & $\begin{array}{c}\text { Visual/ } \\
\text { Verbal }\end{array}$ & $\begin{array}{c}\text { Sequential/ } \\
\text { Global }\end{array}$ \\
\hline Q1. Year of Birth & 0.25 & 0.44 & 0.22 & 0.13 \\
\hline Q2. Time in Academic Libraries & 0.15 & 0.04 & 0.25 & 0.25 \\
\hline Q3. Position Responsibilities & 0.03 & 0.02 & 0.02 & 0.00 \\
\hline Q4. Supervisory Responsibilities & 0.93 & 0.77 & 0.39 & 0.34 \\
\hline Q5. Administrative Responsibilities & 0.25 & 0.38 & 0.68 & 0.49 \\
\hline Q6. Masters in LIS Possession & 0.39 & 0.81 & 0.95 & 0.37 \\
\hline Q7. Type of Institution & 0.86 & 0.32 & 0.16 & 0.11 \\
\hline
\end{tabular}

To determine if there are statistically significant differences in each of the four paired dimension measurements, each question was tested. Most of the $p$-values are greater than 0.05 , meaning that there are no statistically significant differences for the answers to that question (see table 1). For example, there were no statistically significant differences in the Active/Reflective measurement, regardless of the respondents' year of birth ( $p=0.25$, see table 1$)$. However, there are five statistically significant $p$-values; all four paired dimension measurements show statistically significant differences for "Q3. Position responsibilities" and the Sensing/Intuitive measurement shows a statistically significant difference for "Q2. Time in an academic library" (see table 1). Therefore, the results of both these questions were tested further.

In table 2, the letters " $a$ " and " $b$ " are symbols that indicate statistically significant differences between the means within a given column. A mean with the label "a" is not statistically significantly different from another mean with an "a" or "ab," and any " $b$ " labeled mean is not statistically significantly different than another mean with a " $\mathrm{b}$ " or "ab." Therefore, only the means with different letter labels are statistically different from each other. The further testing of "Q2. Time in academic library" yielded no statistical differences (data not shown). The groups highlighted below are the result of further testing of "Q3. Position responsibilities," which allowed the following statistically significant trends to emerge:

- Catalogers are statistically more reflective learners than administrative and instruction librarians, who are more active learners ( $p=0.009$, see table 2).

- Instruction, administrative and the "other librarian" categories are statistically more intuitive learners than catalogers, who are more sensing learners $(p=$ 0.0004 , see table 2). The category "other librarian" consists of librarians who selected the answer "other librarian" in response to "Q3. Position responsibilities" plus the one preservationist as described in the statistical analysis section of this paper. 
- Administrative, cataloging, and reference librarians are statistically more verbal than digital librarians, who are more visual learners ( $p=0.020$, see table 2$)$.

- Administrative, collection development, instruction, and systems/IT librarians are statistically more global learners than catalogers who are more sequential $(p=0.001$, see table 2$)$.

Although the use of the Tukey's post hoc test for mean separation accounts for much of the uneven number of people in each job responsibility group, it is possible that the smaller groups do not show statistical significance due to their lack of a large sample size (see table 2). However, the statistical differences that are observed remain valid. Due to these statistically significant differences, the catalogers, administrative, instruction, reference, digital, systems/IT, and "other librarian" categories will be discussed further. Since the archives, bibliographer/subject specialist, circulation, collection development, electronic resources, interlibrary loan/document delivery, scholarly communication, serials, and special collections librarians did not show statistically significant differences, they are not discussed further.

The position responsibilities that were statistically different from each other are graphed in figures 7 through 10. Although the Tukey's post hoc statistical test showed that catalogers are statistically more reflective than administrative or instruction librarians, the shape of their responses in figure 7 suggests that they are not as different as

\begin{tabular}{|l|c|c|c|c|c|}
\hline \multicolumn{5}{|c|}{ TABLE 2 } \\
\begin{tabular}{|l} 
Means and Significant Differences of Librarians in Different Position \\
Responsibilities for Each Paired Learning Dimension Scale
\end{tabular} \\
\hline & $\begin{array}{c}\text { Sample } \\
\text { Size (n) }\end{array}$ & $\begin{array}{c}\text { Active/ } \\
\text { Reflective }\end{array}$ & $\begin{array}{c}\text { Sensing/ } \\
\text { Intuitive }\end{array}$ & $\begin{array}{c}\text { Visual/ } \\
\text { Verbal }\end{array}$ & $\begin{array}{c}\text { Sequential/ } \\
\text { Global }\end{array}$ \\
\hline Administrative & 321 & $1.00 \mathrm{~b}$ & $1.33 \mathrm{a}$ & $-0.94 \mathrm{a}$ & $1.90 \mathrm{a}$ \\
\hline Archives & 13 & $2.87 \mathrm{ab}$ & $1.86 \mathrm{ab}$ & $-0.79 \mathrm{ab}$ & $2.36 \mathrm{ab}$ \\
\hline $\begin{array}{l}\text { Bibliographer/Subject } \\
\text { Specialist }\end{array}$ & 44 & $0.86 \mathrm{ab}$ & $1.66 \mathrm{ab}$ & $-0.46 \mathrm{ab}$ & $1.66 \mathrm{ab}$ \\
\hline Cataloging & 145 & $3.10 \mathrm{a}$ & $-2.08 \mathrm{~b}$ & $-1.08 \mathrm{a}$ & $-1.18 \mathrm{~b}$ \\
\hline Circulation & 30 & $1.83 \mathrm{ab}$ & $-0.92 \mathrm{ab}$ & $-3.79 \mathrm{ab}$ & $-0.99 \mathrm{ab}$ \\
\hline Collection Development & 94 & $2.32 \mathrm{ab}$ & $0.35 \mathrm{ab}$ & $-1.71 \mathrm{ab}$ & $1.53 \mathrm{a}$ \\
\hline Digital Libraries/Digitization & 40 & $1.63 \mathrm{ab}$ & $1.50 \mathrm{ab}$ & $-4.84 \mathrm{~b}$ & $1.70 \mathrm{ab}$ \\
\hline Electronic Resources & 105 & $2.14 \mathrm{ab}$ & $-0.73 \mathrm{ab}$ & $-1.25 \mathrm{ab}$ & $0.35 \mathrm{ab}$ \\
\hline $\begin{array}{l}\text { Interlibrary Loan/Document } \\
\text { Delivery }\end{array}$ & 14 & $1.81 \mathrm{ab}$ & $-1.75 \mathrm{ab}$ & $-1.73 \mathrm{ab}$ & $-2.01 \mathrm{ab}$ \\
\hline Instruction & & & & & \\
\hline Other & 228 & $0.65 \mathrm{~b}$ & $1.13 \mathrm{a}$ & $-2.13 \mathrm{ab}$ & $1.35 \mathrm{a}$ \\
\hline Reference & 95 & $1.20 \mathrm{ab}$ & $1.10 \mathrm{a}$ & $-2.07 \mathrm{ab}$ & $0.89 \mathrm{ab}$ \\
\hline Scholarly Communication & 11 & $2.63 \mathrm{ab}$ & $2.64 \mathrm{ab}$ & $-1.21 \mathrm{ab}$ & $2.24 \mathrm{ab}$ \\
\hline Serials & 29 & $2.27 \mathrm{ab}$ & $-0.89 \mathrm{ab}$ & $-0.52 \mathrm{ab}$ & $-0.17 \mathrm{ab}$ \\
\hline Special Collections & 18 & $3.16 \mathrm{ab}$ & $1.13 \mathrm{ab}$ & $-0.13 \mathrm{ab}$ & $1.32 \mathrm{ab}$ \\
\hline $\begin{array}{l}\text { Systems/Information } \\
\text { Technology }\end{array}$ & 92 & $1.10 \mathrm{ab}$ & $0.67 \mathrm{ab}$ & $-1.90 \mathrm{ab}$ & $1.45 \mathrm{a}$ \\
\hline$P$ (0.05) & & 0.009 & 0.0004 & 0.020 & 0.001 \\
\hline
\end{tabular}




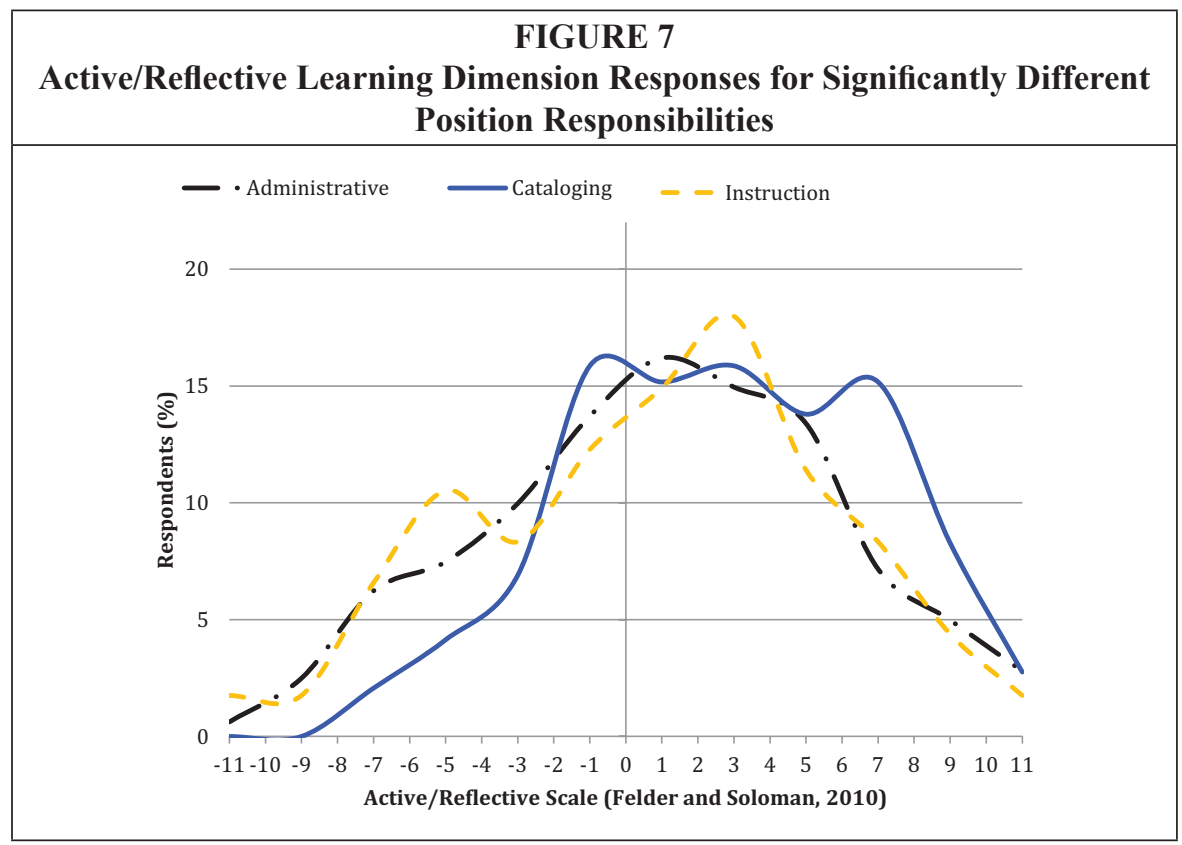

the statistical test would suggest. Cataloger responses can be seen to plateau between -1 and 7 , rather than peak, and are visually very similar to both administrative and instruction librarian responses (see figure 7). This is an example of how the results of a statistical test of significance may be affected by the data failing to meet the assumptions behind the statistical test (that is, that all groups of the data have a perfectly normal, or bell-shaped, distribution).

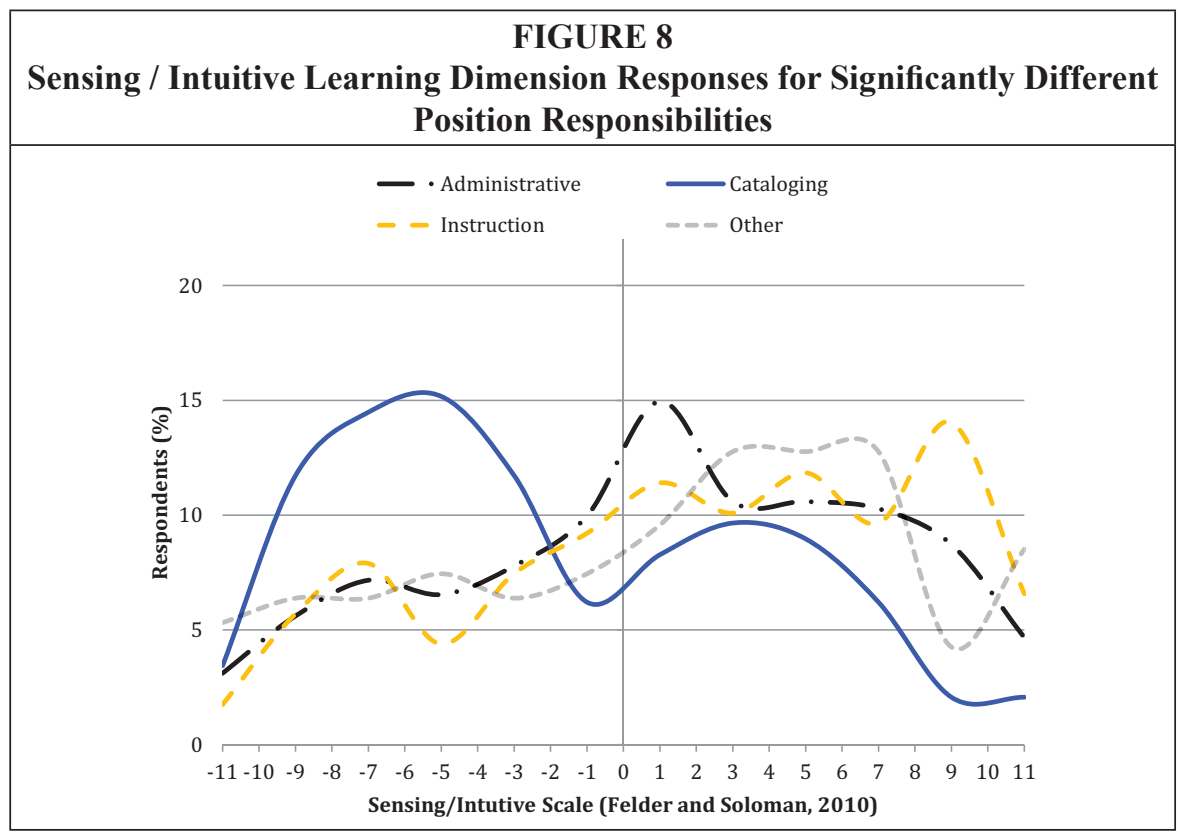




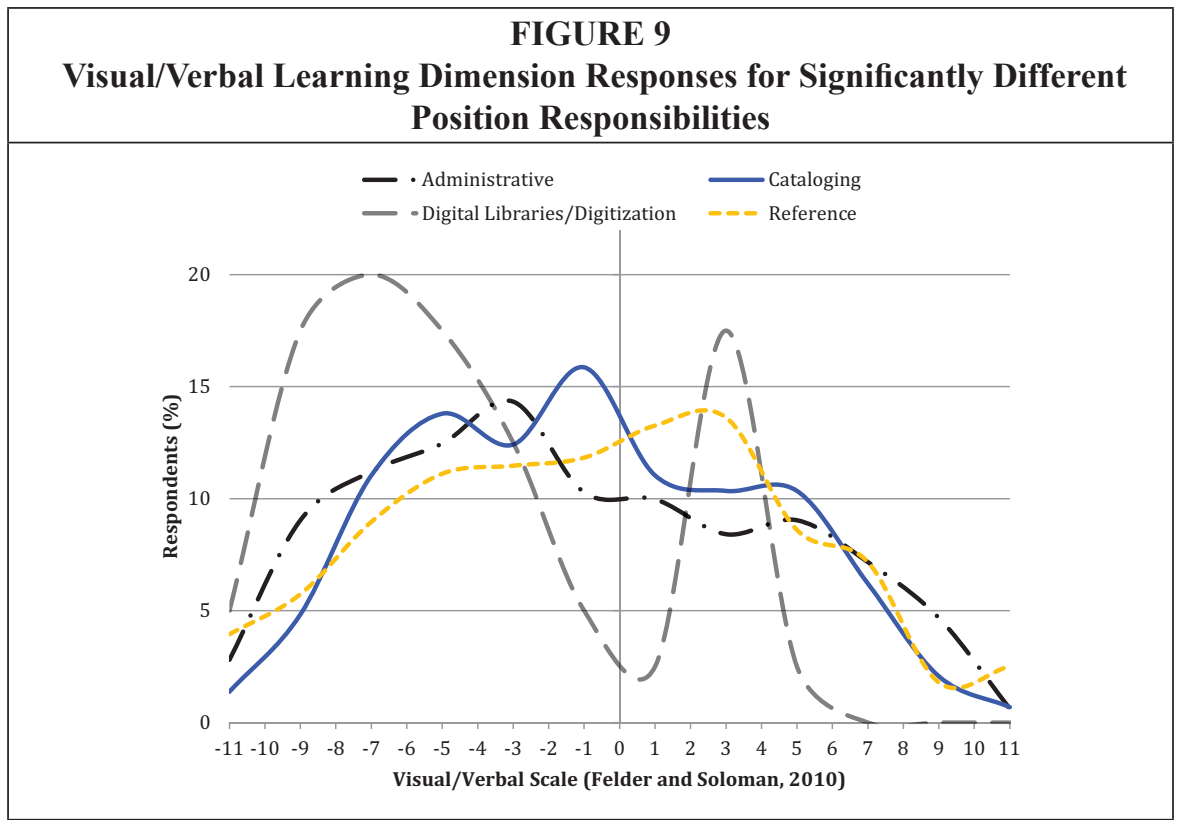

As can be seen from the large number of catalogers that scored on the negative side of the zero mark, they are statistically more Sensing than administrative, instruction, and the "other librarian" category (see figure 8). However, from the shape of the cataloger's distribution, it is possible that they consist of two distinct groups: one that is moderately Sensing and one that is mildly Intuitive (see figure 8).

Similar to the catalogers on the Sensing/Intuitive scale, the digital librarians show two clear groups on the Visual/Verbal scale (see figure 9). One group of digital librarians is clearly moderate to strong Visual learners, while a smaller group is mild to moderate Verbal learners (see figure 9).

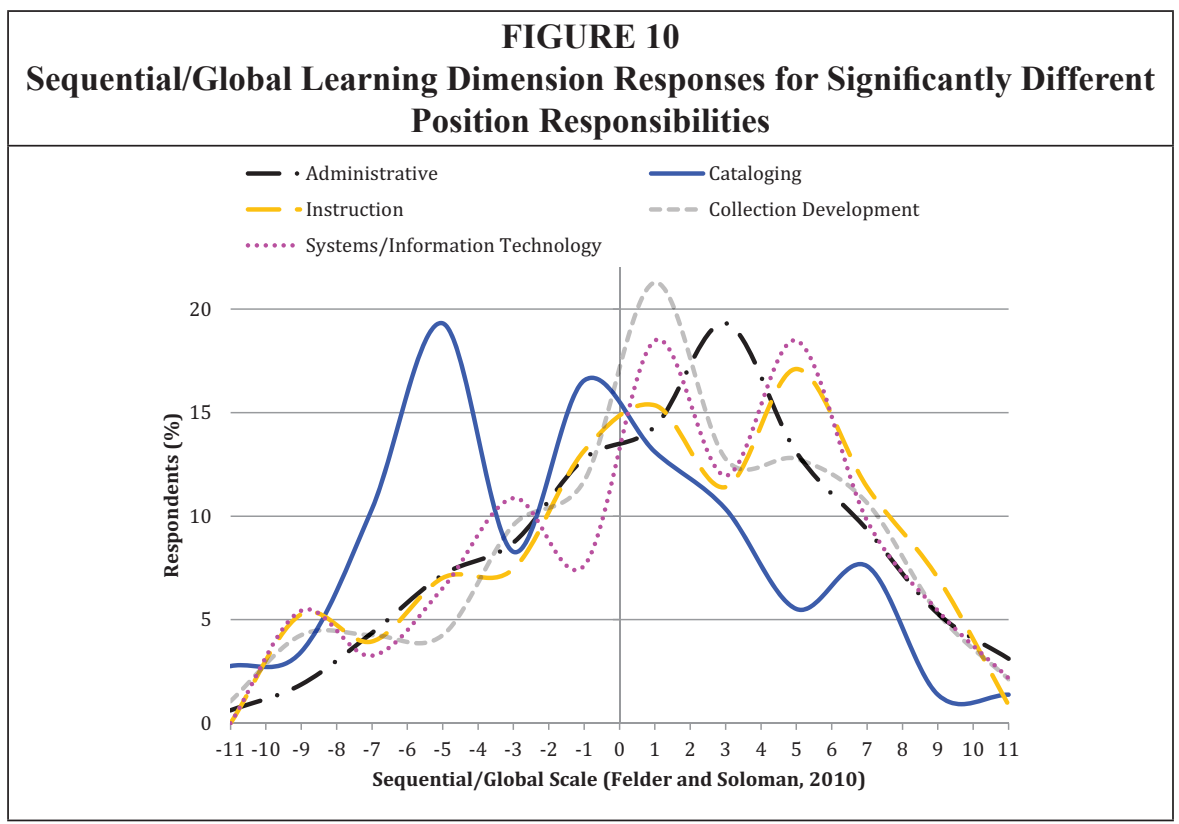


Catalogers also show a tendency toward Sequential learning, while administrative, instruction, collection development, and systems/information technology librarians have a tendency to Global learning (see figure 10). However, the catalogers consist of three apparent groups: moderately Sequential, mildly Sequential and moderately Global (see figure 10).

\section{Discussion}

Although neuroeducational research is in its infancy and learning styles are considered "neuromyths" by some, ${ }^{33}$ the concept of learning styles can be beneficial. ${ }^{34}$ Similar to the Myers-Briggs Type Indicator, ${ }^{35}$ which has also received sustained criticism, ${ }^{36}$ these tools are best used in self-reflective exercises that engage participants in the discussion of differences between individuals. Both tools can be used in a variety of settings to improve workplace interpersonal communication, enhance professional development and staff training, and become a more engaged teacher. Further research could be conducted to determine how these learning dimensions affect a variety of librarian activities.

The findings indicate that some librarians with different position responsibilities have different learning styles. For those participating in professional development, knowing their learning style may encourage individual librarians to either select learning activities that match their learning style or, alternatively, to challenge themselves to engage in nonmatching learning activities. Similarly, librarians who are conducting professional development activities may wish to experiment with teaching styles according to the job descriptions of their targeted audience. For instance, a training activity designed with reflective, sensing, verbal, and sequential components would be complementary to many catalogers' learning styles. Additionally, an understanding of learning styles may encourage managers to be more tolerant of alternative, or nontraditional, professional development activities and be better guided in suggesting learning opportunities for subordinates. Only future research into learning styles and librarian job descriptions will reveal concrete recommendations.

In the classroom setting, learning styles need not be used to prescriptively modify learning materials or attempt to match learning plans to specific individuals, but instead as a framework by which educators can understand the diversity of their students and by which individuals can reflect on their own tendencies in teaching and learning. Both self-awareness and awareness of others' potential differences can enhance teaching and learning. Specifically, learning style assessments may encourage librarian-teachers to recognize when an alternative teaching style is desirable and to expand their teaching style to accommodate a larger variety of learning styles.

From an administrative or manager's stand point, being aware of employees' learning styles can aid in addressing interpersonal dynamics within a department, in meetings, or on a team. When discussion is needed on new information, those with reflective preferences (such as catalogers) may need a longer time to think and process the information. For example, communicating new information prior to a meeting would allow reflective learners enough time to process and be ready to engage in the meeting discussion.

Learning style research could impact the organizational culture of a library and influence how training programs can better address the needs of librarians and the connection (or lack thereof) of learning styles of librarians to the learning styles of students. In conjunction with other established pedagogical theories and practices, learning styles can result in elevated communication and collaboration.

\section{Conclusion}

While current examination of learning styles within librarianship is focused primarily on teaching and student learning, this research study attempts to expand the research 
arena by looking at the relationship of learning styles and professional positions and responsibilities. The researchers hypothesized that learning styles would reflect the type and place of work and the skills and training the librarians possessed. Analysis of the data shows some statistically significant relationships do exist. The observed trends are that catalogers have statistically different learning styles than administrative or instruction librarians. Further research will confirm or refute the trends observed in this study and expose how professional responsibilities are influenced by learning styles, or vice versa.

Specifically, further research could examine more detailed job activities, in addition to the broader job description categories collected here. An examination of job activities would allow researchers to tease out why some learning style dimension answers appear to reflect two or more separate groups, while others clearly reflect one group. This is apparent in the shape of the lines in the graphs; some have a bell-like shape, representing one group, while others show two or more "peaks." It is possible that these "peaks" are related to specific job activities within the job description category.

The use and research of learning styles will continue to engage researchers in multiple areas of scholarship, such as the concepts of learning styles, whether or not they exist, and if learning styles impact how we learn and function within today's society. Continued research will need to ensure a focus on valid measurements and analysis. Even though there are both supporters and critics, thoughtful integration of learning styles into professional development and learning environments can enhance the experience for both teacher and student.

\section{Appendix A. Questions for Survey Instrument}

1. I was born between the following years:

- Before 1945

- 1945-1950

- 1951-1955

- 1956-1960

- 1961-1965

- 1966-1970

- 1971-1975

- 1976-1980

- 1981-1985

- 1986-1990

2. I have been an academic librarian for:

- 0-5 years

- 6-10 years

- 11-15 years

- 16-20 years

- 21-25 years

- 26+ years

- I am not an academic librarian

3. The majority of my position responsibilities are:

- Administrative

- Archives

- Bibliographer / Subject Specialist

- Cataloging

- Circulation

- Collection Development 
- Digital Libraries / Digitization

- Electronic Resources

- Instruction

- Interlibrary Loan / Document Delivery

- Preservation

- Reference

- Scholarly Communication

- Serials

- Special Collections

- Systems / Information Technology

- Other

4. Do you supervise librarians and/or nonstudent staff?

- Yes

- No

5. My level of administrative responsibilities are:

- Library or Library System

- Department

- Unit, Program, or Coordinator

- Other

- I do not have administrative responsibilities

6. I have a Master's in Library and Information Science

- Yes

- No

7. My library is in an institution that is best described as a:

- Doctorate-Granting University-Tier 1/Land Grant

- Doctorate-Granting University-Comprehensive/Non-Land Grant

- Master's Colleges and Universities

- Baccalaureate Colleges

- Associate's Colleges

- Special Academic Institution

- Other

\section{Appendix B. Librarian Listservs for Survey Instrument Call for Participation}

\section{Round One (April 15-May 13, 2011)}

- AAMES-L: ACRL Asian, African, and Middle Eastern Section

- AFAS-L: African American Studies Librarians Section

- ANSS-L: ACRL Anthropology and Sociology Section

- $\quad$ ARLIS-L: Art Libraries Society of North America

- ARTS-LIB: ACRL Arts Section

- CJC-L: ACRL Community and Junior College Library Section

- $\quad$ EBSS-L: ACRL Education \& Behavioral Science Librarians Section

- COLLIB-L: ACRL College Libraries Section

- GOVDOC-L: Government Documents Round Table

- IILAlumni: ACRL Institute for Information Literacy Alumni

- ILI-L: ACRL Instruction Section

- INFOLIT: Information Literacy Discussion (K-20 Collaboration)

- LES-L: ACRL Literatures in English Section

- $\quad$ LIBADMIN: Library Leadership \& Management Association 
- $\quad$ LIBREF-L

- LPSS-L: ACRL Law and Political Science Section

- MEDLIB-L: Medical Library Association

- MLA-L: Music Library Association

- OFFCAMP: ACRL Distance Learning Section

- STS-L: ACRL Science and Technology Section

- ULS-L: ACRL University Libraries Section

- WESSList: ACRL Western European Studies Section

- WGSS-L: WGSS-Women and Gender Studies Section

\section{Round Two (April 15-May 13, 2013)}

- ASIS-L: Association for Information Science and Technology

- Autocat: Library Cataloging and Authorities

- code4lib: Code for Libraries

- DLF-ANNOUNCE: Digital Libraries Forum

- DIGLIB: IFLA discussion list for digital library researchers and librarians

- $\quad$ ERIL-L: Electronic Resources in Libraries

- Liblicense-L: Licensing digital content

- $\quad$ LITA-L: Library and Information Technology Association List

- metadataLibrarians

- NGC4LIB: Next Generation Catalogs for Libraries

- OLAC-L: OnLine Audiovisual Catalogers

- SERIALST: Serials in Libraries

- WEB4LIB: Web Systems in Libraries

- XML4LIB: XML in Libraries

\section{Acknowledgements}

This study was funded by a 2010-2011 Illinois State University Research Grant awarded to Chad Kahl, Bill McMillin, Trisha Prosise, and Jennifer Sharkey. McMillin and Prosise worked on the initial round of research and first draft of the research. Invaluable statistical consulting was provided by Dr. Michael Gizzi and Dr. Mark Leymon of the Illinois State University Department of Criminal Justice Sciences. Preliminary statistical work was done by Ryan Field. The online adaptation of the Index of Learning Styles (ILS) Questionnaire and PHP programming code was done by Steve Farbota. Thanks go to Rong Li, Jason Paul, and Sarah Williams of Milner Library's Library and Information Technology Services Department for technical support. The authors give special thanks to North Carolina State University for their permission to adapt the ILS to our research needs. Thanks are also due to Stephanie Davis-Kahl, Sandy Roe, and Julie Derden for reading drafts.

\section{Notes}

1. Peter Honey and Alan Mumford, The Manual of Learning Styles (Maidenhead, Berkshire, England: P. Honey, 1992); David A. Kolb, Experiential Learning: Experience as the Source of Learning and Development, 3rd edition (Englewood Cliffs, N.J.: Prentice-Hall, 1984).

2. Richard M. Felder and Joni Spurlin, "Applications, Reliability and Validity of the Index of Learning Styles," International Journal of Engineering Education 21, no. 1 (2005): 103-12.

3. Donna Dunning, "Learning Style," in Encyclopedia of Educational Psychology, eds. Neil J. Salkind and Kristin Rasmussen (Thousand Oaks, Calif.: SAGE Publications, 2008), 598-604.

4. Ronald R. Schmeck, Learning Strategies and Learning Styles: Perspectives on Individual Differences (New York: Plenum Press, 1988).

5. James W. Keefe, "Learning Styles: An Overview," in Student Learning Styles: Diagnosing and Prescribing Programs (Reston, Va.: National Association of Secondary School Principals, 1979), 1-17; James W. Keefe, Learning Style: Theory and Practice (Reston, Va.: National Association of 
Secondary School Principals, 1987).

6. Stephen Rayner and Richard J. Riding, "Towards a Categorisation of Cognitive Styles and Learning Styles," Educational Psychology 17, no. 1/2 (1997): 5-27.

7. Ibid.

8. Charles S. Claxton and Yvonne Ralston, Learning Styles: Their Impact on Teaching and Administration (Washington, D.C.: American Association for Higher Education, 1978).

9. Lynne Celli Sarasin, Learning Style Perspectives: Impact in the Classroom (Madison, Wisc.: Atwood Publishing, 1998).

10. Ella Desmedt and Martin Valcke, "Mapping the Learning Styles 'Jungle': An Overview of the Literature Based on Citation Analysis," Educational Psychology 24, no. 4 (2004): 445--64.

11. Frank Coffield et al., Learning Styles and Pedagogy in Post-16 Learning: A Systematic and Critical Review (London: Learning \& Skills Research Centre, 2004), 9.

12. Lori S. Mestre, "Matching Up Learning Styles with Learning Objects: What's Effective?" Journal of Library Administration 50, no. 7 (2010): 808-29; Lori Mestre, "Accommodating Diverse Learning Styles in an Online Environment," Reference \& User Services Quarterly 46, no. 2 (2006): 27-32; Connie Dalrymple, "Perceptions and Practices of Learning Styles in Library Instruction," College \& Research Libraries 63, no. 3 (2002): 261; Paul G. Kussrow and Lucy Harrison, "Learning Styles in the Library: All Students Are Equal, but Some Are More Equal Than Others," Florida Libraries 40 (1997): 128-31; Lorraine Lindsay, "Learning Styles in the Library," School Libraries in Canada 11 (1991): 23-25.

13 Jin M. Choi and Nancy Washington, "Learning Styles of Academic Librarians and Implications for Professional Development," Report No: ED 307892 (1988); Jin M. Choi, “Learning Styles of Academic Librarians," College \& Research Libraries 50, no. 6 (1989): 691-99.

14. David A. Squires, Helen K. Hoopes, and Gary P. Gillum, "Librarians: A Thinking and Learning Styles Portrait," Library Administration \& Management 6, no. 4 (1992): 174.

15. David J. Brier and Vickery Kaye Lebbin, "Perception and Use of PowerPoint at Library Instruction Conferences," Reference \& User Services Quarterly 48, no. 4 (2009): 352-61.

16. Richard M. Felder and Linda K. Silverman, "Learning and Teaching Styles in Engineering Education," Engineering Education 78, no. 7 (1988): 675.

17. Richard M. Felder and Barbara A. Soloman, "Learning Styles and Strategies," available online at http://www4.ncsu.edu/unity/lockers/users/f/felder/public/ILSdir/styles.htm [accessed 5 August 2010].

18. Myron H. Dembo and Keith Howard, "Advice about the Use of Learning Styles: A Major Myth in Education," Journal of College Reading and Learning 37, no. 2 (2007): 101-09; Catherine Scott, “The Enduring Appeal of 'Learning Styles'," Australian Journal of Education 54, no. 1 (2010): $5-17$.

19. Harold Pashler et al., "Learning Styles: Concepts and Evidence," Psychological Science in the Public Interest 9, no. 3 (2008): 105-19.

20. Tzu-Chien Liu Kinshuk and Sabine Graf, "Coping with Mismatched Courses: Students' Behaviour and Performance in Courses Mismatched to Their Learning Styles," Educational Technology Research and Development 57, no. 6 (2009): 739-52; Hong Lu, "The Relationship of Kolb Learning Styles, Online Learning Behaviors and Learning Outcomes," Journal of Educational Technology Society 10, no. 4 (2007); Elizabeth Brown et al., "Reappraising Cognitive Styles in Adaptive Web Applications," in WWW2006: Proceedings of the 15th International Conference on World Wide Web, 23-26 May 2006, Edinburgh, Scotland., eds. L. Carr et al. (New York: The Association for Computing Machinery, 2006), 327-35, available online at http://www2006.org/programme/files/xhtml/1043/ p1043-brown.html [accessed 12 October 2011].

21. Organization for Economic Co-operation and Development, "Learning Seen from a Neuroscientific Approach," in Understanding the Brain: Towards a New Learning Science (Paris: OECD Publishing, 2002), 69-73, doi:10.1787/9789264174986-en.

22. John Geake, "Neuromythologies in Education," Educational Research 50, no. 2 (2008): 123.

23. Richard M. Felder and Joni Spurlin, "Part II: Applications, Reliability and Validity of the Index of Learning Styles," The International Journal of Engineering Education 21, no. 1 (2005): 103-12. Definitions of test-retest reliability, internal consistency reliability, inter-scale orthogonality, and construct validity are provided within the article.

24. Malgorzata S. Zywno, "A Contribution to the Validation of Score Meaning for FelderSoloman's Index of Learning Styles," in Proceedings of the 2003 American Society for Engineering Education Annual Conference \& Exposition (Washington, D.C.: ASEE, 2003).

25. David A. Cook, "Reliability and Validity of Scores from the Index of Learning Styles," Academic Medicine 80, no. 10, Supplement (2005): S97-S101.

26. David A. Cook and Alan J. Smith, "Validity of Index of Learning Styles Scores: MultitraitMultimethod Comparison with Three Cognitive/Learning Style Instruments," Medical Education 40, no. 9 (2006): 900-07. 
27. Charles Hosford and William A. Siders, "Felder-Soloman's Index of Learning Styles: Internal Consistency, Temporal Stability, and Factor Structure," Teaching and Learning in Medicine 22, no. 4 (2010): 303.

28. To see an example of the instrument, visit www.engr.ncsu.edu/learningstyles/ilsweb.html. 29 James Carifio and Perla J. Rocco, "Ten Common Misunderstandings, Misconceptions, Persistent Myths and Urban Legends about Likert Scales and Likert Response Formats and Their Antidotes," Journal of Social Sciences 3, no. 3 (Sept. 2007): 106-16.

30. "Tukey-Kramer Test," in The Sage Dictionary of Statistics, eds. Duncan Cramer and Dennis Howitt (London: SAGE Publications, 2004), 175.

31. K. R. Clarke, "Non-parametric Multivariate Analyses of Changes in Community Structure," Australian Journal of Ecology 18 (1993): 117-43.

32. PROC MIXED with Tukey's mean separation, SAS software, version 9.3, SAS Institute, Cary, North Carolina.

33. P. A. Howard-Jones, "From Brain Scan to Lesson Plan," The Psychologist 24, no. 2 (2011): 110-13.

34. Stephen James Minton, Using Psychology in the Classroom (London: SAGE, 2012), 58-60.

35. The Myers-Briggs Type Indicator is a Registered Trademark of Consulting Psychologists Press.

36. David J. Pittenger, "Measuring the MBTI... and Coming Up Short," Journal of Career Planning and Employment 54, no. 1 (1993): 48-52. 